\title{
An Overview of Factors Influencing Expatriate Job Performance: A Critical Review of Literature
}

Erni Tanius, Mong Faay Jeyakumar Periyannan, Nursyahmina Athirah Azman

To Link this Article: http://dx.doi.org/10.6007/IJARBSS/v11-i12/11469

DOI:10.6007/IJARBSS/v11-i12/11469

Received: 06 October 2021, Revised: 11 November 2021, Accepted: 26 November 2021

Published Online: 20 December 2021

In-Text Citation: (Tanius et al., 2021)

To Cite this Article: Tanius, E., Periyannan, M. F. J., \& Azman, N. A. (2021). An Overview of Factors Influencing Expatriate Job Performance: A Critical Review of Literature. International Journal of Academic Research in Business and Social Sciences, 11(12), 1901-1910.

Copyright: (c) 2021 The Author(s)

Published by Human Resource Management Academic Research Society (www.hrmars.com)

This article is published under the Creative Commons Attribution (CC BY 4.0) license. Anyone may reproduce, distribute, translate and create derivative works of this article (for both commercial and non0-commercial purposes), subject to full attribution to the original publication and authors. The full terms of this license may be seen

at: http://creativecommons.org/licences/by/4.0/legalcode

Vol. 11, No. 12, 2021, Pg. 1901 - 1910

Full Terms \& Conditions of access and use can be found at http://hrmars.com/index.php/pages/detail/publication-ethics 


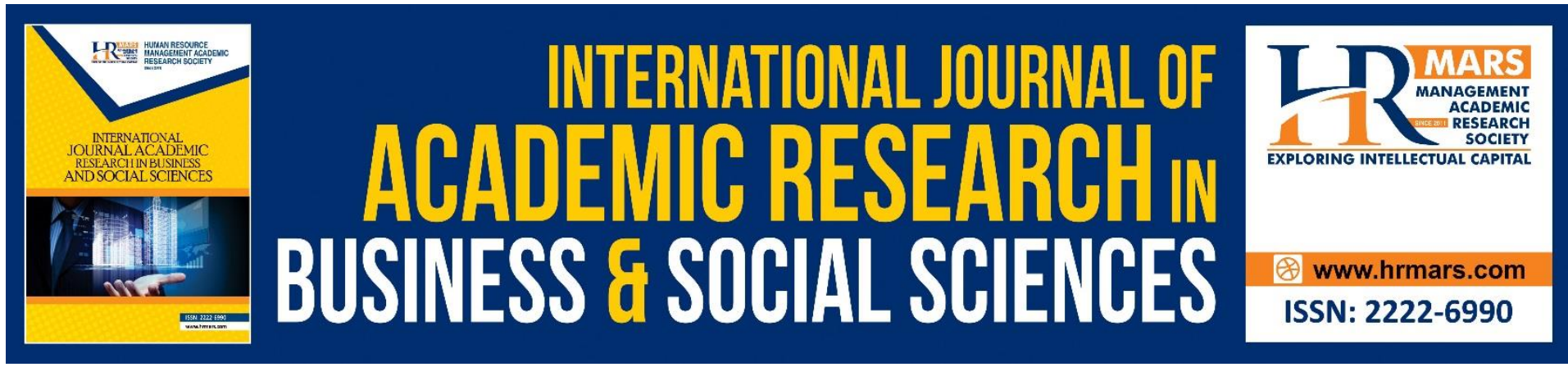

\title{
An Overview of Factors Influencing Expatriate Job Performance: A Critical Review of Literature
}

\section{Erni Tanius, Mong Faay Jeyakumar Periyannan, Nursyahmina Athirah Azman}

Faculty of Business and Accountancy, Universiti Selangor, Jalan Zirkon A7/A, Seksyen 7, 40000 Shah Alam, Selangor, Malaysia.

Email: ernitanius@unisel.edu.my,mong.faay@gmail.com,syahminaazman@gmail.com

\begin{abstract}
Management of the expatriate continues to be a current challenge for many international firms as the competitiveness of the global business environment becomes more challenging than before. The role of expatriates is significant in sustaining the performance of Multinational companies (MNC). Hence, this study aims to identify the main factors that might influence the expatriates' job performance during their international assignments. The data analysis is based on the review of hundred fifty current and related works of literature. The result indicated that three main factors influence the performance of expatriates. They are local language ability, international experience, and the flexibility of the expatriate. Furthermore, the study also suggested that future extensive study is crucial needed. Therefore, it is to ensure the key factors that make the expatriates perform better in their new working environment are identified.
\end{abstract}

Keywords: Job Performance, Local Language Ability, International Experiences, Cultural Flexibility

\section{Introduction}

Expatriate job performance has become the main issue among scholars (Zakariya et al., 2019). Moreover, their roles in Multinational Enterprise (MNE) become more critical, and it becomes a strategic business expansion and development (Zakariya et al., 2019). Hence, organizations need to enhance the expatriate's job performance and effectiveness in executing an international assignment.

As an expatriate, they face many difficulties; as Chen (2019) said, one of the reasons is unfamiliarity with a foreign place and lack of cultural adjustment training. According to Matthew MacLachlan (2018), the international failure rate is over $40 \%$ due to hiring the wrong employee. He added that other reasons the expatriates cannot adapt to their new location, culture, and language barriers. As a result, the organization loses a lot of money (Black \& Gregersen, 2020). Hence, Furusawa (2016) suggested that MNE should manage their expatriates' careers to ensure the smooth adjustment in the new country. 
Rodsai et al (2017) proposed the cultural intelligence and language ability should include in the selection of expatriates. The expatriate fluent in the host language and culture leads to better performance (Ramlan et al., 2018) and a better relationship with host-country employees (Zhang \& Harzing, 2016).

Literature indicates many factors contribute to expatriates' job performance, such as age and international experience (Albrecht, 2018; Michailova, 2016). The other is the flexibility that can increase their cultural intelligence and job performance (Qureshi et al., 2017; Sales, 2017). Furthermore, Sambasivan (2017); Shaffer et al (2006) claimed that there is a positive relationship between the personality traits (cultural empathy and flexibility) of the expatriates and the levels of performance.

The literature shows MNC has a high expectation on expatriates going on international assignments. There are several factors that influence their job performance. Furthermore, the dynamics and diversity of the workplace where the expatriate is positioned could be quite varied. As a result, an expatriate is consistently facing various challenges and issues that are often unexpected by the individual concerned.

This article will start by reviewing the job performance based on the literature, followed by factors that contribute to expatriate job performance since the factors could be broad, so the article is classified into three categories: local language ability, previous international experience, and cultural diversity.

\section{Expatriate Job Performance}

MNC heavily depend on their expatriate performance to sustain themselves in the global market; hence the organization provides some initiatives to improve their performance. The literature indicated that there are many factors that influence the expatriates' job performance; such as Trompetter et al (2016) said the family's ability to adjust themselves in the host location. Meanwhile, Bhatti et al (2015) include the big five personality traits (big five): extroversion, openness to experience, agreeableness, conscientiousness, and neuroticism. The other factors are the adjustment to the socio-cultural and work conditions of the host country (Uddin et al., 2019). The cultural intelligence found positively influences the expatriates' general interaction and work adjustments in the host country. It is directly related to expatriate performance while assigned overseas (Aziz, 2016). Skills, personality, and technical skills also influence expatriate performance (Singh \& Mahmood, 2018). The other factors are information sharing and worker work execution (Swanson et al., 2020), cultural knowledge, social insight, employment execution (Wang, 2016), and occupation execution (Fee \& Gray, 2020).

Therefore, MNE needs to improve their expatriate hiring, training, and support practices (Singh \& Mahmood, 2018). The study conducted by Singh and Mahmud (2018) showed that the job performance of an expatriate depends on their cultural adjustment ability besides the job competencies. Finally, Manan (2016) found that the expatriate's culturally intelligent able to minimize the uncertainty and anxiety that were caused by due to being in a culturally different environment. Hence, an expatriate could use more of their effort for work-related tasks and consequently increase their performance. The study being done by Singh and Mahmud (2018) stated that there is a relationship between emotional intelligence and 
expatriates' performance. In other words, higher levels of cultural adjustment in expatriates will result in better performance through higher emotional intelligence.

Wang (2016) established that expatriates with high cultural intelligence could enhance individual self-adjustment and reduce culture shock. Moreover, they also have excellent job performance in the host country. Lee et al (2018) claimed the cultural adjustment factors contribute to job performance. It is similar to Zhao et al (2020) said practical cross-cultural motivation and objective orientation through cultural adjustment. The cultural adjustments act as a mediator between the mental ability of a person to be mobile and work performance (Zhau et al., 2020). However, Sit et al (2017) highlighted the unexpected obstacles and risks of cross-culture that influence the expatriate's job performance. Finally, Takdir et al (2020) concluded that expatriates are often adaptable and comfortable in cross-cultural interactions, and as a result, increasing the effectiveness of expatriates' job performance.

\section{Local Language Ability}

The most predominant factor that highly influences expatriate job performance is the ability to communicate with the local language in the host country. It is a significant relief for expatriates in the host country, especially the countries that do not use English as a second language. Kobuta (2015) found the Japanese expatriates unable to adjust to China because local employees only use Chinese. Meanwhile, Zhang and Peltokorpi (2015) said that language skills positively affect the host countries on work and work-related adjustment. They also indicated that the function of language in cross-cultural expatriate adaptation is more complex than previously thought. They found that the host country's language skills have multiple effects on expatriate workers. They are interaction with $\mathrm{HCN}$, social support, and $\mathrm{HCN}$ network and non-work-related work.

Furthermore, Abdulai et al (2017) said it creates misunderstanding between the encoder of the message and the decoder of the message. The interactions between expatriate and local staff in MNC subsidiaries are influenced by workplace language (Wilczewski et al., 2018). The role of language leads to job satisfaction (Rodriguez \& Yepes, 2018). Consequently, the ability to speak the local language the expatriate faces challenges for expatriates to perform their international assignments.

It also affects the motivation of expatriates to complete the assignment (Tayaphon et al., 2017). Meanwhile, Zsófia (2016) said that better adjusted local language expatriates tend to be more optimistic about their host culture, thus experiencing less stress, resulting in higher performance. Besides enabling them to optimize, they are performed on the international assignment (Zsófia, 2016). In contrast, failing to understand the local language will lead to poor expatriate performance. Mehtap (2015) highlights that a few barriers will hinder expatriate performance: miscommunication. Rodriguez and Yepes (2018) suggested that language skills are necessary for expatriates to shape social networks, solve workplace problems and acquire skills that enhance job satisfaction. Krishnaveni and Arthi (2015) had also viewed the same findings where they mentioned that language skills are the essential factor that would influence the triumph of the expatriate. Therefore, it significantly affects an expatriate's performance through their language skills in the national host language.

Tahir and Oasis (2020) affirmed that the local language ability would help adapt to the host country. It assists them in enhancing their comfort zones in the host country. Yang (2018) 
highlighted that proficiency in the local language is beneficial for an expatriate for collecting the most helpful data information regarding the local cultures. Hence, it provides them with a better guarantee and safety (Aburge, 2016). Hence, expatriate needs and develop good interpersonal skill (Aburge \& Debrah, 2019). Finally, Matt Shannon (2020) stated that expatriates who can communicate in the local language would be happier with their life. They experience fewer difficulties and find the local people much friendlier than the expatriate who cannot communicate in the local language.

\section{Previous International Experiences}

The expatriate experience in the previous international assignment will motivate the expatriates to perform well in job performance (Suutari et al., 2017). On the other hand, Takeuchi et al (2018) say that job experience and organizational experience largely reflect firm-specific human capital, contributing to organization-specific productivity. Furthermore, Mockaities et al (2018) highlight a relationship between global teams and human resource management in international organizations.

Without experience lead to face barriers and will lead to the failure of expatriation programs (Meyer et al., 2016). Similar to Van der Laken et al (2019), expatriates who have little or no previous international experience would need more social support to adjust to a new physical, cultural, and work environment.

Love et al (2016) said it reflects the regional scale of the export operations of SMEs with nations across regions of the world. Jacob et al (2019) said it contributes to labor market performance. Tan and Sousa (2019) result indicates that the international experience affects innovation capability's moderating impact on performance. Genkova (2016) highlights that a person with international experience has higher open-minded values compared with an individual who has never lived outside the country might not have had as much tension and emotionally demanding circumstances.

Jacob et al (2019) said the potential of this international experience to bring individuals back into the labor market. In addition, the previous experience will impact strategic management and firm performance (Le \& Kroll, 2017). Laken et al (2019) said social support is an essential variable for the expatriate. Furthermore, the international experience results in the career success of assignment expatriates. The majority had been promoted during the eight years' experience (Suutari et al., 2017). Takeuchi et al (2018) define international work experience as a general human capital that serves as a crucial factor in influencing various performancechange trends for expatriates between the three forms of work environments.

\section{Cultural Flexibility of the Expatriate}

Literature found cultural flexibility is another crucial factor that contributes to expatriate performance. Cultural flexibility means the adjustment to unfamiliar cultural environments, the discrepancies in interaction, work, and general adjustment (Kumar et al., 2019). Furthermore, Choudhury and Kwon (2019) said that a job that offers greater flexibility, more autonomy, and better work-life balance might lead to superior individual performance.

Furthermore, Lee and Nguyen (2019) said it would help the expatriate understand why their colleagues in the host country behave differently. Moreover, it has impacts on expatriate's 
effectiveness: work performance, work behavior, and job satisfaction of an expatriate. It is similar to what Singh and Mahmood (2020) found that cultural flexibility is used by the organization to determine the expatriate's work performance. It is to determine the success or failure of an expatriate's work assignment in the host country. Additionally, cultural adjustment acts as a mediator between social competencies and an expatriate's performance. Finally, Naeem et al (2015) concluded that indicated that cultural flexibility could improve an expatriate's work performance. Furthermore, they claimed the inflexibility of culture would influence an expatriate's feelings and declining work performance.

\section{Discussion}

Based on the articles, the dominant factor that contributes to expatriate job performance is the cultural adjustment. It is an adjustment of an expatriate towards the culture in the host country. It is an ongoing process involving learning about a new norm and unfamiliar culture. The more similar their culture, the easier expatriate survive in the host country. Additionally, the higher levels of cultural adjustment will result in better performance through higher emotional intelligence. The next short is culture distance such as foreign language skills; previous overseas experience. Family support and length of employment in a current job were found significant to expatriate job performance. Expatriates with high cultural intelligence could enhance individual self-adjustment and reduce culture shock, consequently increasing job performance.

Hence the literature strongly suggested organizations should develop stronger links between emotional intelligence, cultural adjustment, and job performance. Besides, cross-cultural training is necessary for overseas expatriates to ensure that they can adapt to the new environment and promote their high job performance. As a consequence, the expatriate is able to reduce the unexpected obstacles that may lead to thoughts of ambiguity and anxiety, thus resulting in bad performance. Besides, the adaptable and comfortable in cross-cultural interactions will increase the effectiveness of expatriates' job performance.

Based on the above literature, the ability of expatriates to communicate in the local language with the local workers in the host country greatly influence their performance. It is extremely useful in circumstances of daily life in a foreign country and directly influences their relationships with other expatriate and local workers. Those who can speak the local language are also found able to understand and adjust to the local culture. Subsequently, increase their work performance. Furthermore, they tend to be more optimistic towards their host community and feel less tension. The language skills are also able to influence the triumph of the expatriate and significantly affect an expatriate's performance in the national host language. Hence, its effects on host country national interaction, social support, and networkrelated work and non-work adaptation.

However, it was given relatively little attention in previous expatriate research. Even though it is a critical element for surviving expatriates in the host country, it assists them to learn, adapt to the local cultures, and reduce their seclusion and social isolation. It helps them to better understand the meaning and compassion of diversity too. Finally, the literature proposed that organizations need to improve their global mobility activities to enhance potential performance for their expatriates. As there is evidence, the language ability may affect the motivation of expatriates to complete the assignment. 
The result indicated that the second factors that contribute to expatriate job performance are previous international experience. The literature specified that the career success of expatriates is through international work experience. It is also found as a crucial factor in influencing various performance-change trends among the expatriates in the work environments and the company efficiency. The international experience acts as valuable intellectual capital, helping expatriates to excel in a career that is boundless. Without experience, expatriates are unable to perform effectively and will face strenuous experience.

The previous literature also reported that expatriates with little to no international experience would need more social help in order to adjust to a new working climate. Furthermore, the length of time and cultural distance had a direct and positive effect on firm performance. The literature highlighted that expatriate values and emotional stability are influenced by their previous international experiences. Hence it can conclude that the career success of expatriates and MNC performance as well as their sustainability significantly correlated with the international experience of their expatriates.

Finally, the literature established that the cultural flexibility of the expatriate is greatly related to expatriate and MNC performance. Besides, it has an impact on expatriates' adjustment and effectiveness in a host country. Cultural flexibility is also found as one crucial indicator for expatriates' job performance. It acts as a mediator between social competencies and an expatriate's performance. Cultural flexibility includes cultural empathy; it is the ability to sympathize with others in the host country.

By having cultural flexibility, the expatriate can adjust themselves easily in the host country. Besides, have good knowledge about the mainstream culture and understand their hosts' country attitudes. Moreover, the cultural flexibility and dynamic cross-cultural competencies prominently impacted an expatriate's effectiveness. It includes their work performance, work behaviour, and also the job satisfaction of an expatriate. In conclusion, hostile attitudes, ethnocentric behaviour, and their reaction to host country nationals are the factors that contribute to expatriate cultural flexibility.

\section{Conclusion}

Based on the above discussion, it can conclude that the role of expatriates is very critical, especially in Multi-National Company (MNC) success and sustainability. The literature also reported that the failure rate among the expatriate is high. Furthermore, it found out that the main factors that influence expatriates' performance are local language ability, international experience, and flexibility of culture adjustment.

Overall, the study attempts to provide theoretical support for that local language ability, international experience, and flexibility of culture adjustment factors as predictors for expatriate job performance. Further, this study has a significant impact on expatriates and MNC to be conscious of the factors that they need to highlight before hiring or sending their expatriates to the host country as the literature indicated that the performance of expatriates directly relates to the performance and sustainability of MNC in the global market. Therefore, the right orientation and preparation training is crucial for expatriates to ensure they are able to adjust themselves to the new environment in the host country. The study has also proposed that future researchers should empirically test the result of this study in order to provide 
empirical support. It is also interesting for the future study to include the cross-culture and home country orientation factors that may influence the performance of expatriates.

\section{References}

Abdulai, M., Ibrahim, H., \& Mohammed, M. (2017). Communicating across cultures in multinational Ibis West Africa. International Journal of Intercultural Relations, 58, 4253. DOI: 10.1016/j.ijintrel.2017.04.009

Albrecht, A.-G., Wiernik, B. M., Deller, J., \& Dilchert, S. (2017). The Impact of Age and Experience on Expatriate Outcomes: Success Factors in Private and Public Domains. Managing Expatriates, 131-148.

Aziz, A. M. (2016). The Role of Cultural Intelligence on Expatriate Adjustment and Performance A Case Study of Malaysia. Journal of Administrative Management, Education and Training (JAMET), Vol: 12 No: 4 Pp: 176-197.

Black, J., \& Gregesen, H. (2020). The Right Way to Manage Expats. Harvard Business Review., from https://hbr.org/1999/03/the-right-way-to-manage-expats.

Bussin, D. T. (2016). The relationship between family adjustment and expatriate performance. International Journal of Human Resource Management, Vol: 47 No: 2 Pp: 694-717.

Chen, M. (2019). The Impact of Expatriates' Cross-Cultural Adjustment on Work Stress and Job Involvement in the High-Tech Industry. Front. Psychol., 1-10.

Choudhury, P., \& Kwon, O. (2019). Social Attachment to Place and Psychic Costs of Geographic Mobility: How Distance from Hometown and Vacation Flexibility Affect Job Performance. SSRN Electronic Journal. DOI: 10.2139/ssrn.3517511

Swanson, E. S. K.-J. (2020). The Effect of Leader Competencies on Knowledge Sharing and Job Performance: Social Capital Theory. Journal of Hospitality and Tourism Management, Vol: 42 Pp: 88-96.

Furusawa, M. A. (2016). IHRM and expatriation in Japanese MNCs: HRM practices and their impact on adjustment and job performance. Asia Pacific Journal of Human Resources, 396-420.

Genkova, P. (2016). Experience Abroad and Its Relation to Intercultural Competence and Cross-Cultural Tolerance. International Journal of Business and Management, 11(5), 1.

Hussin, M. S. (2019). Socio-Cultural Adjustment and Job Performance among Expatriates: A Critical Overview. International Journal of Human Resource Studies, Vol: 10 No: 1 Pp: 146-157.

J.Gray, A. F. (2020). Perceived Organisational Support and Performance: The Case of Expatriate Development Volunteers in Complex Multi-Stakeholder Employment Relationships. The International Journal of Human Resource Management, Vol: 31 No: $13 \mathrm{Pp}: 23-36$.

Jacob, M., Kühhirt, M., \& Rodrigues, M. (2019). Labour Market Returns to Graduates' International Experience: Exploring Cross-Country Variation in Europe. European Sociological Review, 35(4), 491-505.

Krishnaveni, R., \& Arthi, R. (2015). An Overview of Multidimensional Factors Influencing Effective Performance of Expatriates. Management, 20, 135-147.

Kumar, R., Budhwar, P., Patel, C., \& Varma, A. (2019). Self-regulation and expatriate adjustment: The role of regulatory fit. Human Resource Management Review, 29(4), 100666. DOI: 10.1016/j.hrmr.2018.09.002

Le, S., \& Kroll, M. (2017). CEO international experience: Effects on strategic change and firm performance. Journal of International Business Studies, 48(5), 573-595. 
Lee, P. Y., Li, C. S. J., \& Wu, M. L. (2018). The roles of cross-cultural adjustment and social capital formation in the dynamic capabilities' development of multiunit organizations. Asia Pacific Management Review, 23(1), 20-29.

Love, J., Roper, S., \& Zhou, Y. (2016). Experience, age and exporting performance in UK SMEs. International Business Review, 25(4), 806-819.

MacLachlan, M. (2018). Why 40\% of Overseas Assignments Fail and What You Can Do to Prevent It. Insight., from https://insights.learnlight.com/en/articles/overseasassignments/

Meyer, B., Meyer Jr, V., Vieira da Silva, K., \& Brandão, L. (2016). Managing expatriates: analyzing the experience of an internationalized Brazilian Company. Revista De Ciências Da Administração, 1(3), 137.

Michailova, D. L. (2016). Expatriate Selection: A Historical Overview and Criteria for.

Mockaitis, A., Zander, L., \& De Cieri, H. (2018). The benefits of global teams for international organizations: HR implications. The International Journal of Human Resource Management, 29(14), 2137-2158.

Nguyen, P., \& Lee, L. (2019). A synthesis of expatriate competence, intelligence, adaptability, work-role demand and organisational support on expatriation effectiveness. International Journal of Services and Standards, 13(1/2), 83. DOI:

10.1504/ijss.2019.10026064

Qureshi, M. A., Shah, S. M., Mirani, M. A., \& Tagar, H. K. (2017). Towards an Understanding of Expatriate Job Performance: A Conceptual Paper. International Journal of Academic Research in Business and Social Sciences, 320-332.

Rodríguez, R., \& Yepes, G. (2018). The impact of the host-country language on international adjustment: Spanish engineers in Germany. Lengua $Y$ Migración / Language and Migration, 10(1), 79-108.

Rodsai, T., Stoffers, J., \& Banowati Talim, M. (2017). Cross-Cultural Adjustment: A Case of Thai Expatriates in Indonesia. The Journal of Applied Business Research November/December 2017, 33(6).

Sambasivan, M., Sadoughi, M., \& Esmaeilzadeh, P. (2017), "Investigating the factors influencing cultural adjustment and expatriate performance: The case of Malaysia", International Journal of Productivity and Performance Management, Vol. 66 No. 8, pp. 1002-1019. https://doi.org/10.1108/IJPPM-10-2015-0160.

Shannon, M. (2019). How Important is Learning the Local Language? / Expatriant. Expatriant., from https://expatriant.com/how-important-is-learning-the-local-language/.

Singh, J. S. K., \& Mahmud, N. H. N. (2018). Emotional Intelligence and Expatriate Job Performance in the ICT Sector: The Mediating Role of Cultural Adjustment. Global Business and Management Research: An International Journal, Vol: 9 No: 1 Pp: 1-16.

Singh, J. S. K., \& Mahmud, N. H. N. (2018). Expatriates Self-Motivation, Competencies, Job Performance and Cultural Adjustment: Empirical Evidence from the ICT Sector in Malaysia. International Journal of Engineering \& Technology, Vol: 7 No: 21 Pp: 185-193.

Sit, A., Mak, A. S., \& Neill, J. T. (2017). Does cross-cultural training in tertiary education enhance cross-cultural adjustment? A systematic review. International journal of intercultural relations, 57, 118.

Suutari, V., Brewster, C., Mäkelä, L., Dickmann, M., \& Tornikoski, C. (2017). The Effect of International Work Experience on the Career Success of Expatriates: A Comparison of Assigned and Self-Initiated Expatriates. Human Resource Management, 57(1), 37-54. DOI: $10.1002 / \mathrm{hrm} .21827$ 
Tahir, R., \& Oasis, D. S. (2020). Expatriate Spouse Adjustment: An Analysis of Challenges Facing Western Female Expatriate Spouses in the United Arab Emirates. Middle East Journal, 7(4), 401.

Takdir, S., Syah, T. Y. R., \& Anindita, R. (2020). Cultural Intelligence Effect on Job Satisfaction over Employee Performance. Journal of Multidisciplinary Academic, 4(1), 28-33.

Takeuchi, R., Li, Y., \& Wang, M. (2018). Expatriates' Performance Profiles: Examining the Effects of Work Experiences on the Longitudinal Change Patterns. Journal of Management, 45(2), 451-475.

Tan, Q., \& Sousa, C. (2019). Why Poor Performance is not enough for a Foreign Exit: The Importance of Innovation Capability and International Experience. Management International Review, 59(3), 465-498.

Van der Laken, P., van Engen, M., van Veldhoven, M., \& Paauwe, J. (2019). Fostering expatriate success: A meta-analysis of the differential benefits of social support. Human Resource Management Review, 29(4), 100679.

Wang, M. (2016). Effects of Expatriates' Cultural Intelligence on Cross-Cultural Adjustment and Job Performance. International Journal of Business and Management, Vol: 55 No: 55 Pp: 231-243.

Wilczewski, M., Søderberg, A., \& Gut, A. (2018). Intercultural communication within a Chinese subsidiary of a Western MNC: Expatriate perspectives on language and communication issues. Multilingual, 37(6), 587-611. DOI: 10.1515/multi-2017-0095

Liu, Y. (2018). Acculturation of Chinese Students in the U.S.: Un-abandoned Chinese Identity and Intra-ethnic Communication. Intercultural Communication Studies, 27(1), 55-71.

Zakariya, H. N., Othman, A. K., Abdullah, Z., \& Abdullah, S. S. (2019). The Relationship between Expatriate Adjustment and Expatriate Job Performance at Multinational Corporations in Malaysia. Academy of Entrepreneurship Journal, 1-11.

Zhang, L. E., \& Harzing, A.-W. (2016). From dilemmatic struggle to legitimized indifference: Expatriates' host country language learning and its impact on the expatriate-HCE relationship. Journal of World Business, 774-786.

Zhang, L., \& Peltokorpi, V. (2015). Multifaceted effects of host country language proficiency in expatriate cross-cultural adjustments: a qualitative study in China. The International Journal of Human Resource Management, 27(13), 1448-1469. DOI: 10.1080/09585192.2015.1072104

Zhao, S., Liu, Y., \& Zhou, L. (2020). How does a boundaryless mindset enhance expatriate job performance? The mediating role of proactive resource acquisition tactics and the moderating role of behavioural cultural intelligence. The International Journal of Human Resource Management, 31(10), 1333-1357. 